\title{
Utopianism and the New World Order: A Critical Consideration
}

\author{
Okoro Kingsley \\ Department of Philosophy and Religion, Ebonyi State University, Abakaliki, Nigeria \\ Email: okoro kingsleyn@yahoo.com
}

Received 23 May 2014; revised 28 June 2014; accepted 11 July 2014

Copyright (C) 2014 by author and Scientific Research Publishing Inc.

This work is licensed under the Creative Commons Attribution International License (CC BY). http://creativecommons.org/licenses/by/4.0/

(c) (i) Open Access

\begin{abstract}
Utopianism, which has been inveigled in various circles into epistemological obscurity, has been the force behind several socio-political and economic reforms of many generations. Scholars accredit religious thoughts as the purveyor of the messianic utopianism, while classical utopianism is accredited to Plato and Aristotle. However, Thomas Moore coined the word utopia and furthered the concept in the modern times. Overly, the power of utopian thinking lies in the strength of imaginative thought. Thus utopianism is christened idealism and dismissed as irrelevant to real life experiences of the modern man. However, the works of Thomas Moore, on the contrary, have thrown hindsight to the fact that utopian thoughts are relevant both for the spiritual and material worlds. Here, utopian thinking serves as a critique to the ineptitude of the utopianist's society. Utopia becomes a means of addressing the evils of the society in which the utopian lives(d). In the works of Thomas Moore, the imaginary city of utopia becomes an ideal state, where all the citizens live in peace and harmony, contrary to the European society of Moore's time, where oppression, war and social disorder were the dicta. Against this backdrop, this paper found epistemological connection between Moore's period and the contemporary period and decided to apply Moore's utopian thoughts to the modern times. It concludes that if Moore's utopianism is applied with modification, the present world will attain its dream of becoming a common community, which extols friendship and brotherhood.
\end{abstract}

Keywords

Utopia (Nism), New World Order, Critical, Consideration

\section{Introduction}

The power of imaginative thinking, which realists call utopia is a pristine gift from the God(s) and this has been a great factor in moving world development and creating visions of future for humanity and the environment. 
Imaginative thinking are not simply based on scientific/theoretical formularies but derived from the regime of intuition. It is like a flash of thought, a bright light thrown to the dark corners of the world. It is always spontaneous and progressive in revelation. Describing the nature of utopian thinking and human capacity to embrace it, Bar (2000), writes:

The human capacity to dream of utopian world is unlimited. The potential for utopia is there, if only we could agree and work it out and make it happen. In the mean time, since through it, we could just put bread on some people's table, they would say "dayenu” that is sufficient. The gap between the potential and actual is so overwhelming that sometimes we want to shed a few tears (1).

Why then do we need to create an utopian thinking in today's world of practical/empirical sciences? The answer is not far-fetched. First, human being cannot live without dreams. Utopian thinking sets goals, provides an image to strive for. By creating an imagery which gives s clear picture of common humanity or new humanity, utopian thinking becomes the fact of life in actuality. Presently, we live in a world plagued with unimaginable horrors of poverty, homelessness in their staggering proportions, violence in all realms of the society, child and women abuses, starvations, wars, holocaust, ethnic cleansing, genocide etc, in contrast to all that the Jewish or Biblical dream of utopia, shared by many people around the world. Jewish utopia creates a dream of sustenance for all-each under his grape vine and under his fig tree, a world filled with the knowledge of God, nation not lifting sword against nation, the wolf and the sheep lying together peacefully (Berje, 2000: p. 1).

Against this background, Hourtart (2011) observes that they may be objections to fanciful utopia; however, he avers that human beings needs utopia while noting that capitalism has destroyed utopian thinking and announced the end of history (34). Notably, utopia has a dynamic dimension, since there will always be tomorrow (Kovel, 2007: p. 24). In creating utopia, social movement, religious organizations and individuals create a vision of the world and the analysis of the reality. Consequently, the ethics of social and political constitutions and the aesthetics expression and self motivation of the actors' essential element in the designing an alternative to the model of capitalist development and the civilization that it transmits are created (Hourtart, 2011: p. 35). The utopian visions create a model that defines and forms part of all the dimensions of new paradigm that our relationship with our fellow human beings and with nature needs. It takes the production of life basic needs, the redefinition of the economic and family seriously. This affects the ways hitherto we conceive the collective and political organizations of societies. In their diversity, these cultural elements can contribute to the change that is necessary for the survival of humanity and the planet.

This paper, having noted that the goals defined by capitalism and the current global economic system propelled by the political forces and transmitted by the dominant culture are not sustainable and cannot ensure the common good of humanity, on the contrary, they work against the continuance of human life (Hourtart, 2009: p. 16), therefore proposes a new paradigm, which will permit a symbiotic relationship between human being and nature, access of all to goods and services and participation of every individual and every collective group in the social and political organization process. The new paradigm shall be anchored on Moore’s utopia.

\section{Utopian Thinking in History}

Utopian thinking has its roots in religious traditions, especially the Biblical tradition of Old Testament (Staver, 1988: p. 1). It was Fotemeh (2011), who pointedly associates the idea with classical Christian tradition (1). According to him, ideal city based on reason comes from Greek and the idea of deliverance through a messiah comes from Christian tradition (2). By means of definition, the word "utopia” is derived from two Greek words "Ou” which means "not" and "topos" which means "place” with the suffice "ia" that is typical of toponyms, we have outopia, which became Latinize as utopia and connotes "no-place-land”. However, the English meaning of utopia in the recent literature is good place. Utopia, therefore, denotes visionary or ideal society, whose members live the best life. Though the idea in the western tradition is traced to Aristotle and Plato, particularly Plato but the term is coined by Thomas Moore in 1516. This was a name he gave to his ideal state in his book "De Optioma republicae Stau deque Nova Insula utopia (Kumar, 1991: p. 17). Utopianism, therefore, refers to the various ways in which people think about and attempt to create a perfect society. Utopian thought deals with morality, ethics, psychology and political philosophy. Utopian idea originates from the belief that reason can be an instrument to bringing about a better society. Accordingly, Ruth (1999) avers that utopianism is usually characterized by the optimism that ideal society is possible and as such plays important roles in motivating social 
and political changes (17). It could be inferred historically that the Western and Classical Christian idea of utopianism were derived from the Old Testament traditions. Thus, Stuver (2011) notes that the establishment of the utopian tradition has its earliest roots in the Old Testament Bible (5). He made allusions to the book of Genesis to justify this position:

Then the Lord God planted a Garden in Eden in the east and he placed there the man whom he had formed out of the ground. The Lord made various trees grow that were delightful to look at and for food with the tree of life in the middle of the garden and tree of knowledge of good or bad (Gen. 2: 8-9).

Accordingly, this passage illustrates man's first utopia, from which he will be exiled and will forever try to attain. Notably, the world "Eden" has an utopian meaning behind it. A similar sounding Hebrew word means “delight” so that the "Garden of Eden” may be synonymous with the garden of delight (Stuver, 2011: p. 7). Nonetheless, most histories of utopia in the West tend to associate it with Aristotle and Plato. In Stuver's (2011) opinion, the utopian tradition also has intellectual and political roots as shown in both Aristotle's Politics and Plato's Republic, which outline government that would best uphold good life (9). Accordingly, these governments develop into primitive utopian state. Consequently, Aristotle and Plato further elaborated on class structure, equality and justice of the utopian state in their respective works (Dixon, nd: p. 4).

In Plato's Republic, the state is described as a place where goodness and justice are required, however, some functions and some values are more important and higher than others and some need take priority (Fotemeh, 2011: p. 2). In this state, Philosophers are at the top of the social order and it hierarchically comes into the base class sustained by the labour class. Then he describes the utopian state, on the one hand, in the imagery of primitive life, while on the other hand, he describes it in relation to poverty and war (Plato 62, Egan, 1997: p. 6). In this dialogue, Glaucon rejects the state and called it a "city of pigs”. However, Socrates countered Glaucon's description of the Plato's ideal city as the city of pigs' when he says, "if you are providing for the city of pigs, how else would you feed beast" (Plato 376:72). He therefore calls that a state of luxurious as well, "People who are to be comfortable are accustomed to lie on sofa and dine off tables and they should have sauces and sweets in a modern style" (Plato 373).

While Socrates was a representative of Plato and his ideals and ideas and Glaucon seems to be a representative of the $20^{\text {th }}$ century man, however both knew what would be going on in the future. Accordingly, it looks as if Plato intended to make his ideality closer to reality of life. Thus, Glaucon confesses at last that a "true and healthy state is just an ideal in the mind. In fact, Plato was portraying a real state, hence coming to choose a guardian, he opted for a man of nobility”, "is not the noble youth very like a well bred dog in respect to guarding and watching” (Plato 375, Fotemeh, 2011: p. 1). Here, Plato began to drift into the deeper issues of mankind as he pays great attention to education as obviously the most important need to protect the luxurious city and the unpredictable man. He went deeper into something high, noble and ideal (Pippin, 1997: p. 26). Plato gave his famous parable in the $7^{\text {th }}$ book, where he portrayed real states of Greece. This parable relates to the future, to the man of modernity, to those away from ideals of life and much more close to real life. Accordingly, reality never dies and it can never be ignored, hence, utopian does not only mean making a city, including the best conveniences and guardians of aristocracy but overly means the making of a man. He notes that all "isms" cannot define man and the reality of his existence, but maintains that man can only be defined if and only if he would live the reality of his life, which is the biggest truth about his nature. Notably, as renaissance was a return to Greek humanism, Platonic conception had some influence on thinkers and architects of that era. Platonic utopia was fixed as it supposed an immutable order and the parameters were the same in all eras. The principles of reason were utilized in rational and scientific arts. Nevertheless, some writers gradually tended to express human protest against Platonic utopianism (Fotemeh, 2011: p. 2).

In the $16^{\text {th }}$ century, Thomas Moore came up with his work titled, “Utopia”. Hence, modern utopia dates from Moore. This drew upon Greek and Christian traditions. To Moore, utopia means a good place that is nowhere (utopia as well as outopia). It seems at all times and in all societies people tend to imagine a paradise or golden age, a place and time that there were no pains, where all lived freely and blissfully. There were some folk images of the land of Cockaygne and Sehlaraffenland, places where man would live joyously and fulfill his wishes. There are the lands El-dorador and Shangil, where people lived in peace and harmony. However, these are not utopia. To Moore, utopia should work with current realities. It is likely that Moore sought to imagine as well as create an imagery of a good and even a perfect society (Fotemeh, 2011: p. 3).

In the $17^{\text {th }}$ Century, we encountered certain utopian works like Campanella's city of the sun (1623), Andrea's 
Christina opolis (1619), Beacon's New Atlantis (1627) and they achieved great fame among European men of letters. Jonathan Swift diminished their fame, when he satirized them by writing Gulliver's travels in 1726. In this work, Swift added the concept of anti-utopia or dystopia to the utopian tradition. Thus from Swift's Gulliver's travels to Samuel Butler's Erewhoo and Evegeny Zamyatins, it has been the hubris of human reason that plays significant role in thinking development and socio-political changes (Kumar, 1991: p. 31). In fact, Joshua Nicholas (1999) did a somewhat summative description of the concept of utopia in history or rather within this period, as he states, "Utopia is fictive representation of an ideal social structure. It seems that utopia is somewhere which is not anywhere except in myths and fiction. Utopia is a mirror held up in the society. It actually reflect the currents state lack of rationality" (461-2) According to him, utopia lies outside of the divinity. Utopia is significant just in relation to the profane city. Consequently, Utopianism-idealism-is any doctrine that has something to do with philosophy and holds that reality is fundamentally mental a construction.

\section{Background and Contents of Moore's Utopia}

Thomas Moore's work on utopianism begins with written correspondence between himself (Thomas Moore) and several people he met on the continents. These were Peter Gilles, the town clerk of Antwerp and Jerome Busleiden, the Counselor to Charles V. Moore chose these letters, which are communications between actual people to further the plausibility of fictional land (Logan \& Adams, 2002: p. 17). The letters include specimen of the utopian alphabets and its poetry. They explain the lack of wide spread travel to utopia during the first mention of the land. Moore's first book tells the traveler, Raphael Hytholoday, whom Moore introduced in Antwerp and it also explores the subject of how best to counsel a prince, a popular topic at Moore's time. The first discussion with Raphael was centered on some ills affecting Europe of $16^{\text {th }}$ Century. Maryan (2011) vividly describes the situation sternly thus:

It can be safely assumed that most utopias are written as a form of critical commentary on the author's own society. Thus, it can hardly be surprising when a philosopher's view of the perfect community differs radically from the community in which he lives. However, in many ways, the author is a product of his own society and thus his work contains biases and preoccupations ingrained in him by his cultural context (12).

Within the period, it was the tendency and priority of kings to start wars and subsequently bleed away money on the futile endeavors (Pagden, 2012: pp. 123-157). In his first work, Moore criticizes the use of execution to punish thieves, saying that thieves murder whom they rob to remove witnesses, if the punishment is going to be the same. He lays most of the problems of theft on the practice of enclosure-the enclosing of common land-and the subsequent poverty and starvation of people, who were denied access to land because of sheep farming. In this regard, Moore attempts to convince Raphael that he would find a good job in a royal court, advising monarchs. In his own words:

I wonder, Raphael how it comes that you enter into no king's service, for I am sure there are none to whom you would not be very acceptable. For your learning and knowledge both of mean and things are such that you would not only entertain them very pleasantly but be of great use to them, by the examples you could set before them and the advices you could give them and by this means you would both serve your own interest and be of great use to all your friends (Moore, 1516: p. 3).

However, Raphael rejected the advice, maintaining that his views were too radical and would not be accepted by the kings of his own time. Raphael sees himself in the tradition of Plato; he knew that for good governance, kings must act philosophically. In his own words as he converses with Moore,

Plato doubtless did foresee, unless kings themselves would apply their minds to studying philosophy or else they would never thoroughly allow the counsel of Philosophers being themselves before, even from their tender age infected and corrupt with perverse and evil opinion (Sullivan, 1983: p. 72).

On his own part, Moore seems to contemplate the duty of Philosophers to work around and in real situation and for the sake of political expediency, work within flawed system to make them better rather than hoping to start from the first principle creating a new regime. He states:

... For in the courts they will not bear with a man's holding his peace or conniving at what others do: a man must bare facedly approve or the worst counsel and consent to blackest design, so that he would pass for a 
spy or possibly for a traitor, that did but coldly approve of such wicked practices (3).

In his books, Moore places utopia in the New World and links Raphael's travels with Amerigo Vespuce's real life voyages of discovery. He suggests that Raphael is one of the 24 men with Vespuce, in his four voyages of 1507, says left for six months at Cabo Frio, Brazil, Raphael then travels further and finds the Island, where he spends five year observing the custom of the natives. Moore describes the Island of utopia brilliantly thus:

... Two hundred miles across in the middle part of the sea, where it is the widest and nowhere much narrow than this except towards the two ends, where it gradually tapers. There ends curved rounds as if completing a circle in five hundred miles in circumference, makes the Island crescent shaped, like a new moon (Logan \& Adams, 2002: p. 27).

The Island was originally a peninsula but a 15 mile wide channel was dug by the community’s founder, King Utopia, to separate it from the main mainland. The Island contains 54 cities. Each city is divided into four equal parts. The capital city Amaurot is located in the middle of the crescent Island. Each of the cities had 6000 households, consisting between 10 to 16 adults. Thirty households are grouped together and elect a Syphogranitus, who Moore called a Phylarchus. Every ten Syphogranti elects Traniborous, Moore recently called a protophylarchus, who rules over them. The 200 syphogranti of a city elect a Prince in a secret ballot. The Prince rules for life, unless he is deposed for suspicion of tyranny. In this arrangement, people are redistributed around the household and towns to keep members even. If the Island suffers from overpopulation, then they create a space in the mainland. Alternatively, the natives of the mainland are invited to be part of these utopian colonies, but if they do not like it and no longer wish to stay they may return to the mainland or to their native homes (Kaleb, 1963: p. 61). However, in the situation of under population, the colonies are recalled (Kumar, 1979: p. 7).

In the city of utopia, there is no private ownership but goods are stored in warehouses and people request what they need. The houses in Utopia are built by the government and assigned to citizens freely. The houses rotate among citizens for a period of ten years. Consequently, there are no locks on the doors. In this city, agriculture is the most important job. Thus every person in the Island is taught farming, and as such it becomes compulsory for citizens to embark on agriculture as matter of primacy. To support agriculture, every citizen of utopia must learn at least one of the other essential trades like weaving - this is mainly done by the women, carpentry, metal smiting and masonry. There is deliberate simplicity about these trades, for instance, all people wear the same type of simple clothes and there are no dress makers, making other different stylish apparels. All able bodied citizens must work, thus unemployment is drastically eradicated in utopia. The people work only for six hours a day. However, they may willingly work longer. In this city, Moore allows scholars to become rulers or priest. These are picked during their primary education for their ability to learn. All other citizens are encouraged to apply themselves to learning in their service (Moore Book 2).

Slavery is part of the life in the city. Every household is permitted to have two slaves. The slaves are either from other countries or are utopian criminals. The utopian criminals are weighed down with chains of gold. The gold is part of the wealth of the country and faltering criminal with it gives the citizens a deadly dislike for it. It also makes it difficult to steal as it is in plain view. The wealth is of little importance as it is only good for buying commodities from foreign nations or bribing these nations to fight each other. However, slaves are periodically released for good behaviour. Other significant innovations of utopia include: a welfare state with free hospitals, euthanasia is only done by the permission of the state. In utopia, priests are allowed to marry, while divorce is permitted and pre-marital sex punished by a lifetime enforced celibacy and adultery is punished by enslavement. In the utopian state, meals are taken in community dining halls and the responsibility of feeding the population is rotated among the households. Travels on the island is only permitted with an international passport and people found without a passport are on the first occasion returned in disgrace, but after a second offence, they are placed into slavery. In addition, there are no lawyers and law is made very simple as all should understand it and not leave people in doubts of what is right or wrong.

Wives are subject to their husband and husband to their wives. However women are required to conduct the household's tasks for most part. Widows are sometimes allowed to take priestly office; both the men and the women are trained in military arts. Women confess their sins to their husbands on monthly basis. Gambling, hunting, makeup and astrology are discouraged in utopia. Utopians do not like to engage in war. If they feel countries friendly to them have been wronged, they will send military aid to them. However, they try to capture rather than kill enemies. They are upset if they achieved victory through bloodshed. To the utopians, the main 
purpose of war is to achieve that which if they had achieved already they would not have gone to war. Privacy is not regarded as freedom in utopia, thus taverns, ale-houses and places for private gathering are non-existent, for the reason of keeping all men in full view, so that they are obliged to behave well.

It is the evil of leadership failures in Europe of Moore's time that prompted him to enunciate the political theory or principles in the state of utopia. Some of these leadership failures are discussed in book 1 and addressed in book 2, which now gave rise to utopian political structure. Justifying this position Moore wrote in his book 1

As he told us of many things that were amiss in those new discovered countries, so he reckoned not a few things both which patterns might betaken for correcting the errors of these nation among whom we live, of which an account may be given as I already promised (3).

Presenting the case in a dialogue with the Cardinal, Moore maintains that the increase of pasture by which sheep, which are naturally mild and easily kept in order, may be said now to devour men and people, not only villages, but nations, for wherever it is found that sheep of any soil, a softer and richer wool than ordinary, there the nobility and gentry, and even those holy men, the abbots, not content with the old rent which farms yield, nor thinking it enough that they living at ease, do no good to the public, resolve to do it hurt instead of good. They stop the course of agriculture, destroying homes and nations, reserving on the churches and enclose grounds that they may lodge their sheep in them. As if forest and parks had swallowed up too little of the land, those worthy countrymen turn the best inhabitated places into solitudes, for when insatiable wretch, who plague to his country reserves top enclose many thousand acres of ground, the owners as well as the tenants are turn off their possession by tricks or by force, or being wearied out with ill-usage, they are forced to sell them. By which means those vulnerable people with their poor but numerous families, are forced to change their seats, not knowing whither to go and they must sell almost for nothing their household stuffs, which could bring them much money, though they might say for a buyer. When that little money is at an end, for it will be soon spent, what is left for them to do, but either to steal and so to be hanged or to go about begging? And if they do this, they are put in prison as idle vagabonds, while they would willingly work but can find none, which will hire them, for there are more occasion for which country labour; which they have been bred, when there is no arable ground left. One shepherd can look after a flock which will stock an extent of ground that would require many hands if it were to be ploughed and reaped. These likewise in many places raise the price of corn.

The price of wool is also raised that the poor people are no more able to buy it and this likewise makes many of them idle. For since the increase of pasture, God has punished that avarice of owners by a rot among sheep, which has destroyed vast number of them, to us it might have seemed more just fell on the owners themselves. But suppose the sheep should increase, their price is not likely to fall since though they cannot be called a monopoly, because they are not engrossed by one person, yet they are in few hands and these are so rich that they are not pressed to sell them sooner than they have a mind to it. So, they never do it until they have raised the price as high as possible. On the same account, the other kind are so costly because many villages being pulled down and all country labour being much neglected, there are none who make it their business to breed them. The rich do not bred cattle as they do sheep but they buy them lean and at low prices and after they had fattened them on their ground sell them again at high rates.

In the same vein, luxury breaks in a pace upon the nation to set forward poverty and misery, hence there is an excessive vanity in apparel and great cost in diet and that not only in nobleman's families but even among tradesmen, among the farmers themselves and among all ranks of persons. You have also many infamous houses and besides those that are known, the taverns and ale-houses are no better, added to these, dice, cards, tables, football, tennis and quoits in which money runs fast away and those that are initiated into them, must in the conclusion betake themselves to robbing for a supply. Banish these plagues and give order that those who have dispeople so much soil may either rebuild the villages they have pulled down or let out their ground to such as will do it, restrain those engrossing of the rich that are as bad almost as monopolis, leave fewer occasions to idleness, let agriculture be set up again and for the manufacture of wool be regulated so that there may be work found for those companies of idle people, who want forces to be thieves or who now being idle vagabonds or useless servants, will certainly grow thieves at last if you do not find remedy for these evils. It is vain thing to boast of your severity in punishing theft, which though it may have the appearance of justice, yet in itself is neither just nor convenient, for you to suffer your people to be ill-educated and their manners to be corrupted from their infancy, and then punish them for those crimes for which their first education disposed them, what else is to be con- 
cluded from this but that you first make thieves and then punish them? It is these social evils created by the state of social inequality that made Moore begin to think on how to make the society more humane and the law governing the people has human face and feeling. Therefore he created an utopian state as an answer to his quest of a dream state. It therefore suffices that often utopia are not reserved for the hereafter but for the here now experiences.

\section{Hermeneutical Discussions and Application of Moore's Utopian Thinking to the Modern Age}

Utopian thinking is generated for two purposes in any age. The first aims at creating an escape route from the miseries of the world and to give a sense of hope for a better world to come as against the present hopeless and dehumanizing world. The second is that it may challenge the present debilitating hopeless and humiliating conditions. It does this by creating an ideal state, "an ought" state of both political and economic relationship that ameliorates the suffering of mankind. Against this backdrop Fotemeh (2011) writes:

Utopia has its roots in classical and Christian belief, the ideal city based on reason comes from Greek and the idea of deliverance through a messiah, comes from Christians... To Plato utopia is a form of ideal city, a prefect one, it fulfils by its political, social spatial organization. ...it seems at all times and in all societies people tend paradise or golden age, a place and time that there is no pain, all live freely and blissfully. These are folk images of the land of Cockaygne and Sehlaraffend land, places where man would live joyously and fulfill his wishes. There are El dorados and Shangril Las, where people live in peace and harmony (12).

Okoro and Osunwoke (2013) maintaining the religious base of utopian aver that in many cases the concept is expressed in religions terms and tradition with philosophical traditions like Taoism, Confucianism, Hinduism, Judaism, Christianity and Islam and as well as traditional religions of the indigenous people (27-38). The present existential/experiential reality with its bedrock firmly founded in oppression, marginalization, violence, conflict and war has become a source of concern for the global citizens that we need to create an utopia to address these mind bugling human conditions of our time. This is done with the hope that such will refocus the present order to a bright future as against the present hopeless and futureless state that humanity of $21^{\text {st }}$ century are immersed. The quagmire in which the present generation found herself is described by Okoro (2011) aptly thus:

... The human race has entered a schizophrenic-like state from which it cannot possibly emerge without being re-shaped to the roots of its being. Without such transformation, our chances of survival are just about nil (256). Our chances of surviving even for ten or twenty years are 50-50. There are shorter life expectations that people have ever had in the world before. In short, the human race has found its way to the centre of a steel trap so cumulative and depth-structured that there may be no way out-no way in short of some sort of spontaneous reorganization of our collective self (257).

In doing such a critical rethinking on utopia that may result in the required reshaping, we shall adopt the taxonomy of Hourtart Francois (2011) as our model. This model touches on the four major areas of relationship.

1) Relationship with nature.

2) Economic relationship.

3) Democratic/political relationship.

4) Intercultural relationship.

\subsection{Our Relationship with Nature}

In the utopian thinking of Thomas Moore, the land received of substantial treatment. The land was regarded with respect as everybody in the Island of utopia regarded himself more as a tenant and caretaker of land than its owner and exploiter (More books 11). Moore's utopia simply describes a new way in which an ideal society should relate with nature. This is simply a reaction to the widening gap between western way of living that destroys and the traditional way of living that maintains harmony with nature. With the periscope of utopian thinking in our modern times, one underscore the basic fact that modern civilization with its strong control over nature and its high degree of urbanization, has made human beings forget that, we depend totally on nature for our lives. Hourtart (2011), therefore, underscores that climate change reminds the modern man the reality of his 
inseparable relationship with nature (21). The implication of the assumption is that considering nature as planet and as natural resources that can be reduced to the status of saleable commodities is a violation of life and its true essence. The utopia thinking in all ages maintains that nature's power to regenerate itself physically and biologically has to be treated with respect. Conversely, any relationship with nature that is exclusively utilitarian must be questioned and consequently jettisoned (Kovel, 2007: p. 28).

On his own part, Kovel (2007) proposes that capitalist thinking, which is overtly anti utopianism, considers ecological damage as collateral and inevitable - to be reduced as far as possible. For him ecological damages are externalities since they are ignored in market calculations and in the accumulation of capital (28). Whereas in the Moore's utopian thinking, it rightly pointed out that human beings are part of nature and that the dichotomy should not exist between the two but they shall live in a symbiotic state. This idea are well represent in the works of the Brazilian Theologian, Leonard Boff, which influenced the President of UN General Assembly, Miguel D' Escoto, in his farewell address in 2009 as he proposed a Universal Declaration of the right of the mother-earth and of mankind (Hourtart, 2009: p. 72). This same assembly has previously approved through the votes of 192 counties the adoption of a mother-earth Day. Therefore, it is generally accepted in many intellectual circles that a shallow anthropocentric attitude towards nature that consider human beings as the centre of the world without taking into account other living being, including the planet itself is serious epistemological flaw.

Notably, it is only human beings that are responsible for the destruction of the ecosystem. Against the backdrop, the jurist, Antonio Salamanca, used as justification for this proposition the legal categories of direct subsidiary or secondary law which compels the human community to act on behalf of the incapable, who for the reproduction require human mediation (Hourtart, 2011: p. 22). In technical sense, this position is not mere anthropocentrism of Boff and Co but Anthropo-responsibilisante- that is making human being aware of their responsibilities. In this way, by broadening the concept of the judicial subjects, one can speak of criminate justice without necessarily resorting to the personalization of the earth and its elements. At the same time, it cannot be ignored that there is a link between the relations that humans have with nature.

Overtly, in great philosophical traditions of the east, the deep bond between the humans and nature is a central theme of thoughts. Thus respect for all life, such as we find in Hinduism and Buddhism points vividly to this conviction as does the belief is Samsara - reincarnation as an expression of the unity of life and its continuance (Hourtart, 2011: p. 22). The belief that man was created from clay (the Earth), which we find in Judeo-Christian tradition and subsequently taken up in Islam expresses the same idea. Therefore, the bible maintains that mankind is a guardian of nature and not its exploiter (Gen.1: 26-28) Even if it also maintains that nature is to serve man, this obviously does not include destruction of it. In various African communities, the creation myths points to the similar idea of the inseparable relationship between human beings and nature. These myths evidenced the fact that the Earth is simply a central support system for all lives and as such should be treated with respect.

However, in the modern times, this pristine and priceless relationship between man and nature has been violated. It was Karl Max, who first foresaw this violation as he maintains that capitalism has provoked an artificial and mechanical separation between nature and human beings (Players, 2010: p. 17). Accordingly, the rupture in metabolism, that is the material exchange between the earth and the satisfaction of the needs of human beings, such as defined by the capital accumulation process, has ended up in irrational practices, wastage and destruction. According to Marx, this reason has generated the idea that the reduction of the natural energy flows in a way that is socially fair, so as to ameliorate the quality of life. According to him, only socialism can re-estab- lished the metabolic balance and put an end to the destruction of nature. He therefore calls for a new concept of our relationship between humankind and nature. This is an utopian thinking in the modern age.

\subsection{Economic and Production Relationship}

Thinking on economic relationship in the utopian Island, Moore stipulates:

... And though they know exactly how much will serve every town and all that track of the country which belongs to it, yet they sow much more, and breed more cattle than are necessary for their consumption and they give that over plus of which they make no use to their neighbours when they want anything in the country in exchange for it ... (Moore Book II).

Moore's utopian thinking has come to challenge our current thinking on economic and production relationship. Notably, the economic transformation paradigm of Moore concerns itself with giving priority to "use value" in- 
stead of "exchange value" as is the rule of capitalism. "Use value" matrix is adopted when a commodity or service is useful to the life of someone, rather than being simply the object of a transaction (Hourtart, 2011: p. 26). On the first hand, market economy gives priority to "exchange value" for capitalism, the most developed form of market production places premium only on "value". A good or a service that cannot be converted into merchandize has no value, because it does not contribute to the accumulation of capital (Hourtart, 2011; Godeller, 1982). According to this view, "use value" is secondary value and acquires the right to exist if it adjust to the requirement of “exchange value” (Meszaros, 2008: p. 49). Of course, any goods, which are not at all useful can be produced as long as they are paid for or if artificial needs are created through advertising (Dersens, 2011; Hourtart, 2011: p. 26), or of the financial services are expended through speculative bubbles. In contract, putting the expression "use value” makes the market serve human needs.

Overtly, the concept of necessity is relative; it changes according to historical circumstances and the development of productive forces. The principle is that all human beings have the right to satisfy their necessities. This is emphatically affirmed by the Universal Declaration of Human Rights. However, this cannot be achieved in abstract, but in well structured and defined economic, social and political circumstances. Thus, relativity does not mean a fair inequalities, some having more needs than others, according to their class, gender and ethical origin (Hourtart, 2011: p. 26). The satisfaction of needs must be defined by the human community at different levels through a democratic process and by a competent body, like the representatives and the senators in the utopian Island of Thomas Moore. This could be described as a "moral economy" World Council of Churches (WCC, 2005), describing this moral economy as Agape relationship states inter alia, “Agape relations affects all dimensions of life. Life includes having food, clothing, shelter, education, work, and health. Life includes, social belonging, relationship, social self realization, experiencing and celebrating community as well as the gift's participation" (14). Moral economy, on its own, must be subjected to ethical requirement that contradicts the predominance of the exchange value, as a source of accumulation of capital (Stem, 2006; Hourtart, 2011: p. 27). It may not be possible to achieve such a mission of economic bliss in the present socio-economic order, without first of all challenging the private ownership of principle means of production, which is what places decision making power in the hands of the holders of capital goods and subordinates labour to capital, both directly through wages and indirectly through other mechanisms like monetary policies, national debts and budget deficits, speculations on the price of food and energy, the privatization of public services (Brie, 2011: p. 62). It is the exclusive control of capital over production process that contributes to the degradation of working condition and the devaluation of women's work, which is so essential for the reproduction of life in its entire dimension. It is noted that the total state control as a counter weight to the total market is not also a satisfactory solution, as past socialist experiences show. Thus, there are many forms of collective control, from cooperative to citizens association (Hourtart, 2011: p. 27).

Therefore, what we need is redefinition of economy that will vie way from the current definition that considers production as an aggregate value for the benefit of the owners of mean of production or of financial capital. The new definition will see economy as a collective activity aimed at ensuring the basic needs of the physical, cultural and spiritual lives of human being on the planet. Hence, world economy that is based on the exploitation of work to maximize profit must be jettisoned as in the production of goods and services destined for 20 percent of world population, who have relatively high purchasing power, excluding the remaining 80 percent because they do not produce any "added value" and have insufficient income. Redefining the economy therefore means a fundamental change, which will privilege the "use value paradigm" which involves the development of productive process and presupposes the adoption of the first fundamental element, that of respect for nature. The new paradigm does not exclude exchanges necessary to satisfying the new "use values" but on the condition that they do not create imbalances in local access to use value and that they include externalities in the process.

Thus, to prioritize use value over exchange value means the rediscovering of the territorial aspect of human relationship in all economics. Notably, Globalization has caused the people to forget the virtues of local proximity in favour of global outer changes thereby ignoring externalities and giving primacy to financial capital (Hourtart, 2009: p. 28). However, territorial spaces, as the site of economic activities, the political responsibility and culture exchanges are the place to introduce another kind of rationale. However, it is not a matter of reducing the question to a microcosm but rather to think in terms of multidimensionality, in which each dimension, from the local unit to the global sphere has its function without destroying the others. Thus, the concept of food sovereignty and energy sovereignty, by which trade is subordinated to a higher principle, the satisfaction of the requirement of the territories dimensions are mere illusion in a strictly global regime (Hourtart, 2011: p. 28). 
This is because in the capitalists' perspective, the law of value imposes priority for commercialization and hence it yields precedence to export of crops over the production of food for local consumption. Hence, on the one hand, the idea of food security is not adequate, because it can be ensured by trade that is based on the destruction of local economics, on the over specialization of certain areas of the world and on globalize transport that is a voracious consumer of energy and polluter of the environment.

On the other hand, social economy is built on a logic that is quite different from that of capitalism. It is true that it is a marginal activity at present compared with the immense concentration of oligopolistic capital but it is possible to encourage it in various ways. The same goes for corporative and popular credit. They must be protected from being destroyed or absorb by the dominant system. As for regional economic initiative, they can be the means of a transformation out of economic logic, on the condition that they do not represent simply an adaptation of the old system to new production techniques, thus serving as means to integrate national economies into a capitalist framework at a higher level. To restore the common goods privatized by Neoliberalism is a fundamental step to be taken in public services like water, energy, transport, communication, health, education and culture. This does not necessary mean the state taking them over but rather setting up many different forms of public and citizens control over their production and distribution. Thus, the redefinition of the common good of humanity against the backdrops of a new definition of economy as shown in all utopian thinking, is thus a necessary task to be undertaken, confronted as we are by the destruction of our common heritage as a result of forgetting the collective dimension of production for life-needs and by the promotion of exclusive individualism.

\subsection{Democratic/Political Relationship}

Here our focus shall be on how to generate a working democracy or democratic system that will not only overhaul the political system but touch the field of economics, relationship between men and women and of course all social institutions. In the words of Hourtart (2011), the move from democracy, which are often used to establish a fake equality and to perpetuate unacknowledged social inequalities must be left behind (29) The conceptual shift will affect our understanding of the state and the reclamation of human right in all dimensions, individual and collective as were evident in the utopian thinking of Thomas Moore. The new Paradigm will involve the consideration and treatment of every human being with no distinction of race, sex or class but as partners in the building of a new society. This new concept will confirm the self worth and participation of every citizen of the state in all the vital realm of the governance in the state.

The Concept of the state is quite central in this field. Thus the model of French revolution, which seeks to erase all differences in order to construct citizens, who were in principle equal, may not be enough to building a true democracy. However, such an idea is still a novel when compared to the political structure of the European ancient regime. Nevertheless, it is now necessary not only to take into consideration the existence of opposing classes and to realize that any one class or a coalition of them can take possession of the state to ensure their own interests dominate (Hourtart, 2011: p. 30). Thus to acknowledge the existence of all the various nationalities that live within a territory and who have the right to affirm their cultures, their territorial reference point and their social institutions is a great step towards achieving real democracy.

This is not a matter of falling into the kind of communalism that weakened the state, as happened in certain European countries in the neo liberal era or of accepting the neo anarchism of certain legislature and massive protests. It is not also a matter of retreating into nostalgia for a romantic past, like certain politio-religious movements, nor falling into the clutches of power economic interest that prefer to negotiate with small-scale local boarders. Our new model aims at reaching equilibrium between these different dimension of collective life, international, regional and local, recognizing their existence and setting up mechanism for participation. The new model takes into account the situation of the most marginalized social group, landless peasant, the women and other lower caste, which have been ignored for millennium now. It also considers the situations of the indigenous people of all continents, America and Africa inclusive, who have been excluded for over 500 years. Since the judicial and constitutional realms have shown evidence of their incapacity to change the situation of oppression and racial prejudiced in the society, we then employ the cultural factor as a decisive means of the new model in defining a real democracy.

Furthermore, the social policies that protect people against oppression by the "global market" and providing for the basic necessities of the world citizens as in the Thomas Moore's utopian state constitute an important step in the transition process, provided they are not considered as just a form of charity, detached from structural re- 
forms. The generalization of democracy should also apply to the dialogue between political entities and social movements. Thus, the organization of bodies for consultation and dialogue must be part of the model, respecting mutual autonomy. Here, we note that the concept of civil society often used in modern era, remains however ambiguous because this too is a ground where class struggle takes place. In reality, we do not have a bottom-up civil society and a top-down one. The unqualified use of the term makes it possible to create confusion and present social solution that overlook class differences (Dierkersen, 2010: p. 72).

\subsection{Inter Cultural Relationship}

The objective of the cultural dimension is to give to all forms of knowledge, cultures, philosophies and religion an equal chance of contributing to a better human society. This cannot be the exclusive role of western culture, which in reality is identified with the concept of development, which eliminates all other aspects. To undertake this project means not only an understanding of reality or its anticipation but also the necessary ethics for elaborating the common society of our dream. Multiculturalism entails the adoption of the organizational principles of the three other categories already discussed. The relationship with nature, the production of life basic needs and the organization of democracy on a broad space. It is also important for the transition of ideas and values within different peoples. To speak in everyone's language and express oneself in culturally comprehensible terms is an essential requirement of democracy.

On the one hand, multiculturalism is not enough. Thus, open interculturalism is here advanced, with dialogue between cultures and opportunities for exchange. Notably, cultures are not simply artifacts meant for the museum, but it is the living element of any society. Culture consists of internal and external migrations, linked to development of means of communication, which have created many changes. Clearly, not all of them are desirable but which can be enriching. It is manifested in parts in education and in communication media as well as in various opportunities to express culture-like pilgrimages, religious agents and buildings etc (Hourtart, 2011: p. 32).

On the other hand, the notion of interculturalism must also have influence on general education, like the teaching of history and reshaping of an education Philosophy at present guided by the logic of market. Communication media are quite important here as they transmit not only information but also values. Through this means the problem of the modern society is handled in holistic manner through interculturalism, as it promotes local cultures, to counteract monopolies and destroy the dominance of a handful of international agencies. Consequently, ethical bodies, such as Association for the defense of human rights, watchdog groups of various kinds, religious institutions, are given the opportunity to express themselves within the model of interculturalism.

Culture here must include spiritual dimensions which are characteristics of human beings, raising them above the concern of everyday life. This is a central theme in a period when civilization is in crisis. All over the world there is search after meaning, for the need to redefine the very aim of life. Spirituality is the force that transcends the materials world and gives it a meaning (Kovel, 2007: p. 18). The sources of spirituality are many and are always to be found within a social context; they cannot exist without a physical and sociological base (Hourtart, 2011: p. 33). The human being is indivisible; spirituality presupposes matter that, on the other hand, has non sense without spirit. Thus a culturalistic understanding of spirituality, ignoring the material aspects of a human being — which for an individual is the body and for the society is the economic and political reality-is a conceptual aberration leading to reductionism or alienation. Notably, spirituality, (with or without reference to a supernatural), gives a sense of worth to human life on the planet. How this may be expressed as conditioned by the social relation in the society but it can also give direction to these relations. No change of paradigm can be carried out without spirituality, which has many paths and multiple expressions.

The vision of the world, the understanding and analysis of reality, the ethics of social and political considerations and the aesthetics expression and self-motivation of the actors are essential element when designing alternatives to the model of capitalist development and the civilization that it transmits. They form part of all the dimensions of the new paradigm; our relationship with nature, the production of basic life needs, the redefinition of the economy and finally the way in which we conceive the collective and political organizations of societies. In all their diversity, these cultural elements can contribute to the change that is necessary for the survival of humanity and the planet.

\section{Conclusion}

This paper has done a critical survey of utopian thinking, revealing its implications and practicability in the modern 
world. The paper reveals also that utopian thought is born from the premise that through reason and intelligence, man is capable of creating an ideal society in which every individual can achieve fulfillment without infringing on the happiness and well being of other members of the society. Utopian ideas though may never be fully realized here, still play important roles in bringing about positive social change. They allow thinkers to distance themselves from existing reality and to consider new possibilities. The optimism that a better world is a possibility provides a motivation and a focal point for those involved in bringing about social and political changes.

Utopian thinking as found in the works of Thomas Moore generates a complete theoretical rethinking, which handles all the elements that have led the world into systemic crisis situation and with the wearing out of a historical model. It also redefines the objectives of new social construct that is respectful of nature and capable of ensuring human life as a shared endeavour (Hourtart, 2011: p. 34). The reference of any new paradigm of human development in life in its concrete reality which includes relations with nature, which in fact is negated by the logic of capitalism.

Though utopian thinking in every generation has also been questioned and rejected as idealistic, the fact still remains that human beings needs utopia to face the harsh realities of life as caused by capitalism. Utopia has always a dynamic dimension that there is always tomorrow embodied as a central theme of its ideas. Utopia is a call to advance. The need for utopia is felt in all major circles of human organizations of the modern society. The numerous social movements, the citizen organizations, political groups, all these struggle on their own to attain better relationship with nature and for its protection, for peasant and organic agriculture for social economy, for the abolition of illicit debts, for collective taking over of the means of production and for the primacy of work over capital, for defense of human rights, for participatory democracy and for the recognition of the value of different cultures. This redefined the need to revisit and apply utopian thinking into the social political and economic paradigm of the modern age.

\section{References}

Bar, J. C. (2000). Utopianism and Realism in Judaism. Tuesday Torah Lecture Series, New Jersey: Communication Commission.

Berje, M. (2000). Religious Utopia in the Age of Violence. New York: MaryKnoll.

Brie, M. (2011). Making the Common Good of Humanity Concrete. Brussels: Rosa Luxemburg Foundation

De Schuller, O. (2011). Eco-Farming Can Double Food Production. Geneva: High Commission for Human Right.

Dierkersen, S. (2010). Modern Society and Modern Economy: A Review. www.Humansociety.edu://justice.org://html

Dixon, H. (nd). Analyzing Resolution Equality in "Plato's Republic”. Texas: Free Communication.

Egan, M. (1997). Ibsen: The Critical Heritage. London: Rutledge.

Fotemeh, E. (2011). Utopia Thinking-From Plato to Ibsen and O'Neil. London: Critical Heritage.

Godeller, M. (1982). Humanity and Values in the Modern World. www.humanvalues/marketeconomy.edu/html

Hourtart, F. (2009). Eccamimo: A la utopia desde un mundo de incertidumbre. Panam: Ruth Casa

Hourtart, F. (2011). From “Common Goods” to the "Common Good of Humanity”. Brussels: Rosa Luxemburg Foundations.

Joshua, N. (1999). Lucan, the City and the Utopian Symptom: An Analysis of Abject Urban Spaces. London: Oxford University Press

Kaleb, G. (1963). Utopianism and Its Enemies. New York: Free Press

Kovel, J. (2007). The Enemy of Nature - The End of Capitalism or the End of the World. London: Zed Books.

Kumar, K, (1979). Utopia and Anti-Utopia in Modern Times. Oxford: Black Well

Kumar, K. (1991). Utopianism. London: Taylor and Francis Group.

Logan, G. M., \& Adams, R. M. (2002). Utopia. New York: Cambridge University Press.

Maryan, R. M. (2011). The Role of Women on Plato’s Republic and Thomas Moore’s Utopia. www.utopianism./edu.org

Meszaros, K. (2008). The Man and the Market. New York: Oribis Books.

Moore, T. (1516). Utopia Book 1. www.Utopia.edu.org

Okoro, K. N. (2011). Towards a New World and New Humanity: Radindranath Tagore's Model in Conscious Connectivity. In M. Brenner (Ed.), Creating Dignity in Conversion (pp. 255-271). Charleston, VA: Lexigngton K.Y.

Okoro, K. N., \& Osunwoke, C. I. (2013). Common Humanity not Common Community: The Solution to Global Crisis. 
African Journal of Political Science and International Affairs, 7, 12-23.

Pagden, M. K. (2012). Tha Language of Political Theory in Early Modern Europe. www.modernhoalthough./edu.pagdon/org Pippin, R. (1997). Idealism as Modernism. Cambridge: Cambridge University Press.

Players, G. (2010). After Globalization-Becoming Actors in Global Age. Cambridge: The Poultry Press.

Ruth, L. (1999). Concept of Utopia: Utopianism and Communitarianism. Syracuse: Syracuse University Press.

Staver, C. (1988). Religious Utopia and Modern Development. NJ: Edumund Publishers.

Stem, M. (2006). Report on the Economy of Climate Change. London: The Treasury Press.

Stuver, A. L. (1998). The Destruction of Utopia. Frostbrog: Frostbrog State University.

Sullivan, E. D. S. (1983). The Utopian Vision: Seven Essays on the Quintessential of Sir Thomas Moore. San Diego, CA: San Diego State University Press.

Dersens, W. (2011) Re-Thinking Modern Economic System. www.moderneconomy.edu://justice.org/html

World Council of Churches (WCC) (2006). Alternative Globalization Addressing People and Earth. Geneva: Peace and Creative Forum. 
Scientific Research Publishing (SCIRP) is one of the largest Open Access journal publishers. It is currently publishing more than 200 open access, online, peer-reviewed journals covering a wide range of academic disciplines. SCIRP serves the worldwide academic communities and contributes to the progress and application of science with its publication.

Other selected journals from SCIRP are listed as below. Submit your manuscript to us via either submit@scirp.org or Online Submission Portal.
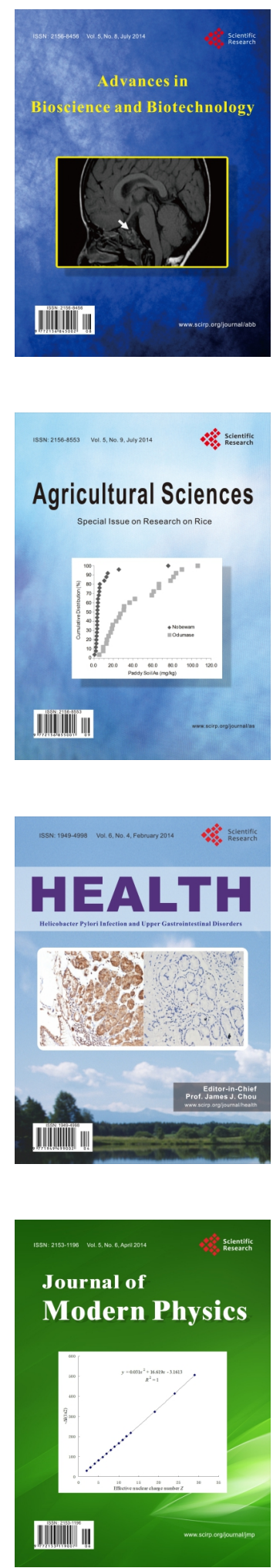
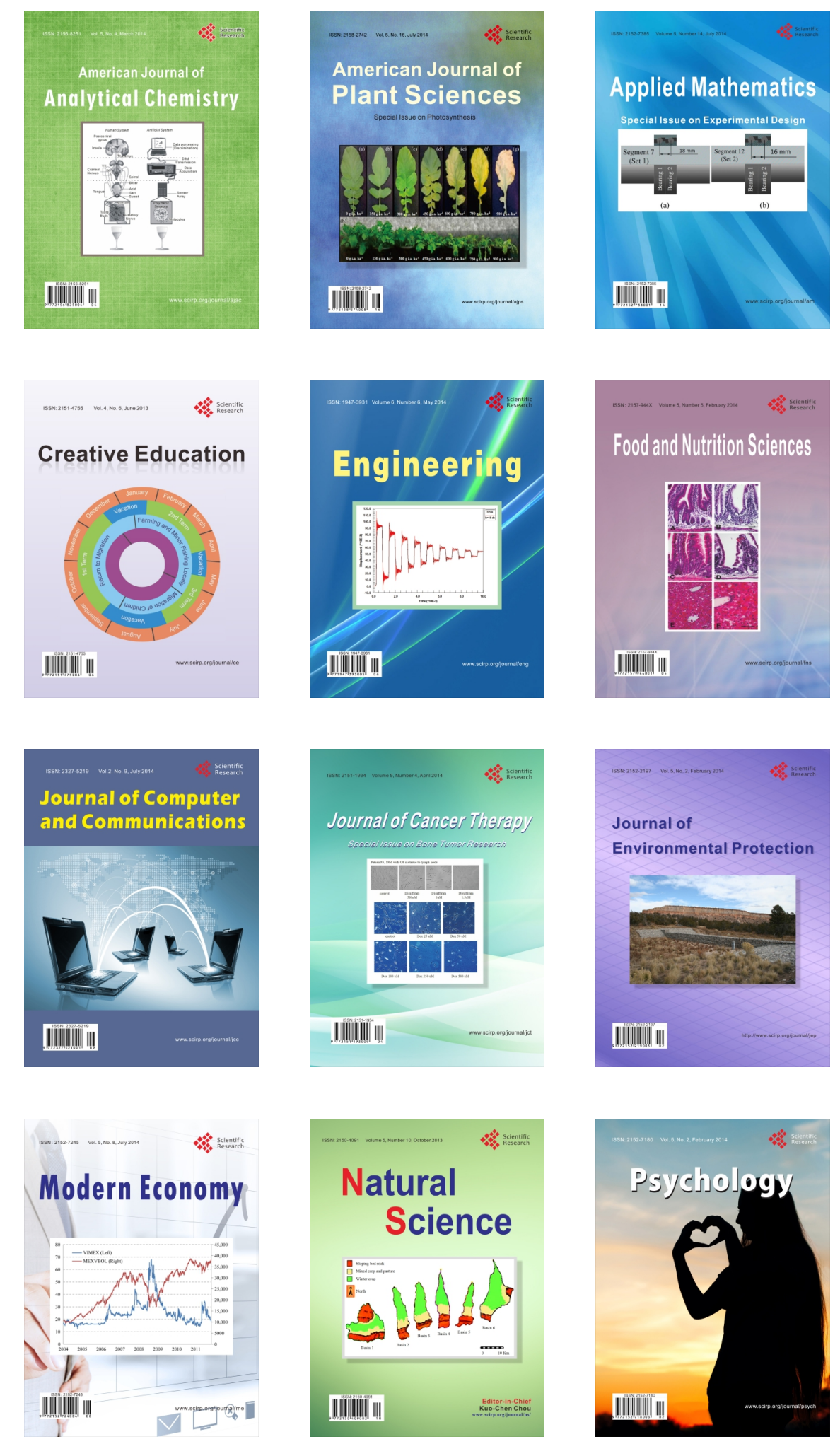